\title{
Pregnancy Related Acute Kidney Injury at a Tertiary Care Center in Nepal
}

\author{
Paudyal P, Pradhan N, Bista KDB, Rawal S \\ Department of Obstetrics and Gynaecology, Tribhuvan University Teaching Hospital, Kathmandu, Nepal
}

Received: March 05, 2014; Accepted: January 7, 2015

Aims: This was performed to study the characteristics of Pregnancy Related Acute Kidney Injury (PRAKI), its management and outcome in patients at a tertiary level referral centre.

\begin{abstract}
Methods: A hospital based prospective observational study was conducted in Tribhuvan University Teaching Hospital (TUTH) over a period of 18 months. All patients diagnosed with PRAKI were included in the study. Patient profiles in terms of age, parity, gestational age were studied along with time of occurrence of PRAKI, preceding event, etiology, management and maternal outcome. Descriptive and univariate analyses were conducted and qualitative variables were expressed as percentages while quantitative variables as means.
\end{abstract}

Results: There were fifteen cases of PRAKI during the study period with incidence of 2.1 per 1000 deliveries. The average age was $25.23 \pm 3.8$ years and $9(60 \%)$ were primipara. Fourteen $(93.3 \%)$ developed PRAKI in the postpartum period with $10(66.6 \%)$ cases following Lower Segment Caesarian Section (LSCS). The commonest etiology of PRAKI was severe preeclampsia/ Hemolysis, Elevated Liver enzymes, Low Platelet (HELLP) syndrome and pregnancy hemorrhages each consisting 4(26.6\%) cases. The stage of Acute Kidney Injury (AKI) according to RIFLE (Risk, Injury, Failure, Loss, ESRD-End Stage Renal Disease) criteria was as follows: risk in $1(6.6 \%)$, injury in $3(20 \%)$ and failure in $11(73.3 \%)$ cases. Hemodialysis was necessary in $12(80 \%)$ cases while 3 cases $(20 \%)$ improved with medical management only. The average duration of hospital stay was $25.2 \pm 14.7$ days and $7(46.6 \%)$ needed ICU admission. Twelve $(80 \%)$ cases recovered completely while two patients were dialysis dependent at the time of evaluation. There was one death.

Conclusions: PRAKI occurred mainly in the postpartum period with severe preeclampsia/HELLP syndrome and hemorrhages as the most common causes. It is associated with high maternal morbidity, prolonged hospital stay and even mortality. Multidisciplinary team management is essential.

Keywords: acute kidney injury; postpartum; PRAKI; pregnancy.

\section{INTRODUCTION}

Acute kidney injury (AKI) is a clinical syndrome denoted by an abrupt decline in glomerular filtration rate (GFR) sufficient to decrease the elimination of nitrogenous waste products (urea and creatinine) and other uremic toxins. ${ }^{1}$ Pregnancy Related Acute Kidney Injury (PRAKI), though uncommon, causes significant maternal and fetal morbidity and mortality. New cases of PRAKI have declined from approximately $1 / 3000$ in the 1960 s to $1 / 15,000-$ 20,000 in recent times. ${ }^{2}$ Two main factors may be responsible for the overall decline in the incidence of PRAKI: improvement in pre-natal care and a decrease in the rate of illegal, septic abortions in developed countries.

\section{CORRESPONDENCE}

Dr Pooja Paudyal

Department of Obstetrics and Gynaecology, Tribhuvan University

Teaching Hospital. Maharajgunj, Kathmandu.

Email: paudyalpooja@yahoo.com

Phone: +977-9841526853
Usually, the development of AKI during pregnancy follows a bimodal distribution with two incidence peaks: one in the first trimester, caused by septic abortion and the other in the third trimester, due to late obstetric complications such as uterine hemorrhages, preeclampsia, hemolysis, elevated liver enzymes, low platelet (HELLP) syndrome, acute fatty liver of pregnancy, and Thrombotic Thrombocytopenic Purpura-Hemolytic Uremic Syndrome(TTP-HUS). ${ }^{3,4}$ AKI is reported in approximately $1 \%$ of women with severe preeclampsia and 3 to $15 \%$ of women with HELLP syndrome. ${ }^{5,6}$

Despite a favorable trend in incidence rates worldwide, maternal and perinatal morbidity and mortality remain significant problems in developing countries and management of PRAKI is extremely challenging in low resource settings. There is no published data on this problem in Nepal. Ours being a referral centre with dialysis and renal transplant facilities, we do see such cases with increased morbidity and mortality. This study was therefore done to assess the 
problem, its causes and outcome so that we can better understand and care for these patients.

\section{METHODS}

This hospital based prospective observational study was conducted in the Tribhuvan University Teaching Hospital, Kathmandu, Nepal over a period of 18 months from $1^{\text {st }}$ Baisakh 2070 to $31^{\text {st }}$ Asoj 2071 (April 14, 2013 to October 17, 2014). Ethical clearance was obtained from the Institutional Review Board (IRB) of Institute of Medicine. All pregnant and postpartum patients who developed PRAKI were included in the study. Patients with preexisting renal disease or renal insufficiency before pregnancy were excluded. Patients were enrolled in this study once PRAKI was diagnosed according to the definition given below and after taking informed consent from the patient. Patients were classified during analysis into stages of RIF (Risk, Injury, Failure) according to the maximum stage reached. The causes of AKI, its characteristics, need for dialysis, and the outcome (improved, partial recovery/loss of renal function, ESRD) were examined prospectively. For this study, data was collected regarding different aspects; (i) Population: age, parity, follow up status (ii) AKI: time of occurrence, preceding event, biochemical parameters, management, time to start of diuresis, hospital stay, need for intensive care, RIFLE stage and etiology (iii) Maternal outcome in the form of complete recovery of kidney function, partial recovery of kidney function, dialysis dependence and death.

Descriptive and univariate analyses were conducted using the SPSS 17 software. Qualitative variables were expressed as percentages and quantitative variables as means.

\section{Definitions}

(i) Acute kidney injury was defined as an abrupt (within $48 \mathrm{~h}$ ) reduction in kidney function defined as at least one of the following: $(i)$ an absolute increase in the serum level of creatinine of $26.4 \mu \mathrm{mol} / \mathrm{L}(0.3$ $\mathrm{mg} / \mathrm{dL}$ ) or more; (ii) a percentage increase in the serum level of creatinine of more than $50 \%$ (a 1.5 fold increase from baseline); or (iii) a reduction in the volume of urine output (oliguria $<0.5 \mathrm{~mL} / \mathrm{kg}$ hourly for $>6 \mathrm{~h})$. $^{7}$

(ii) AKI was classed according to risk of renal dysfunction; injury to the kidney; failure of kidney function, loss of kidney function, and end-stage kidney disease (RIFLE) criteria based on changes in serum creatinine or changes in urine output, or both. RIFLE criteria include three levels of renal dysfunction and two clinical outcomes: "loss" and "end-stage renal disease" (ESRD). ${ }^{8}$

RIFLE criteria for AKI

\begin{tabular}{|c|c|c|}
\hline Class & $\begin{array}{l}\text { Glomerular } \\
\text { filtration rate } \\
\text { criteria }\end{array}$ & $\begin{array}{l}\text { Urine output } \\
\text { criteria }\end{array}$ \\
\hline Risk & $\begin{array}{l}\text { Serum } \\
\text { creatinine x } 1.5\end{array}$ & $\begin{array}{l}<0.5 \mathrm{ml} / \mathrm{kg} \\
/ \mathrm{hr} \times 6 \mathrm{hrs}\end{array}$ \\
\hline Injury & $\begin{array}{l}\text { Serum } \\
\text { creatinine } x 2\end{array}$ & $\begin{array}{l}<0.5 \mathrm{ml} / \mathrm{kg} / \\
\mathrm{hr} \times 12 \mathrm{hrs}\end{array}$ \\
\hline Failure & $\begin{array}{l}\text { Serum creatinine } \\
\mathrm{x} 3 \text { or serum } \\
\text { creatinine } \geq 4 \mathrm{mg} / \mathrm{dl} \\
\text { with an acute } \\
\text { rise }>0.5 \mathrm{mg} / \mathrm{dl} \text { _ }\end{array}$ & $\begin{array}{l}<0.3 \mathrm{ml} / \mathrm{kg} / \\
\mathrm{hr} \times 24 \mathrm{hrs} \\
\text { or anuria } \\
\text { x12 hrs }\end{array}$ \\
\hline Loss & $\begin{array}{l}\text { Persistent acute } \\
\text { renal } \\
\text { failure=complete } \\
\text { loss of kidney } \\
\text { function }>4 \text { weeks }\end{array}$ & \\
\hline $\begin{array}{l}\text { End stage renal } \\
\text { disease (ESRD) }\end{array}$ & $\begin{array}{l}\text { End stage } \\
\text { kidney } \\
\text { disease }>3 \text { months }\end{array}$ & \\
\hline
\end{tabular}

(iii) PRAKI was defined as development of AKI at any time during pregnancy and postpartum period.

(iv) Maternal Outcomes:

Complete recovery- Patient recovered complete kidney function

Partial recovery- partial recovery of kidney function to make the patient dialysis free for some time.

ESRD- no recovery of kidney function, patient is dialysis dependent and requires kidney transplantation.

Death

\section{RESULTS}

Fifteen cases of PRAKI were admitted to the hospital during the study period. Incidence was 2.1 per 1000 deliveries (15 out of 7108 deliveries). Their ages varied from 20 to 33 years, with an average of $25.23 \pm$ 3.8 years (Table 1). Parity ranged from $1-4$ and primipara were $9(60 \%)$ while multipara were $6(40 \%)$ with an average parity of $1.5 \pm 0.91$ (Table 1 ). 


\begin{tabular}{|lccc|}
\hline \multicolumn{4}{|l|}{ Table 1. Age and Parity of PRAKI patients $(\mathrm{n}=15)$. } \\
\hline Age (yrs) & N (\%) & Parity & N (\%) \\
$16-20$ & $1(6.6)$ & P1 & $9(60)$ \\
$21-25$ & $9(60)$ & P2 & $4(26.6)$ \\
$26-30$ & $4(26.6)$ & P3 & $1(6.6)$ \\
$31-35$ & $1(6.6)$ & P4 & $1(6.6)$ \\
\hline
\end{tabular}

Of the 15 cases, $11(73.3 \%)$ were referred cases whereas $4(26.6 \%)$ patients were our booked (having previous antenatal visit in our hospital) cases. Most patients, 14(93.3\%) developed PRAKI in the postpartum period while 1 was after a late first trimester abortion (Table 2).

\begin{tabular}{|c|c|c|c|c|c|}
\hline $\begin{array}{l}\text { Occurrence } \\
\text { of } \\
\text { PRAKI }\end{array}$ & $\mathrm{N}$ & $\%$ & $\begin{array}{l}\text { Preceding } \\
\text { event }\end{array}$ & $\mathrm{N}$ & $\%$ \\
\hline Antepartum & 1 & 6.6 & $\begin{array}{l}\text { Septic } \\
\text { abortion }\end{array}$ & 1 & 6.6 \\
\hline \multirow[t]{2}{*}{ Postpartum } & 14 & 93.3 & $\begin{array}{l}\text { Vaginal } \\
\text { delivery }\end{array}$ & 4 & 26.6 \\
\hline & & & LSCS & 10 & 66.6 \\
\hline
\end{tabular}

Of the 14 postpartum cases, 4(26.6\%) were following vaginal delivery [1-stillbirth, 2-Intra Uterine Fetal Death (IUFD) expulsion, 1-Normal Vaginal Delivery] and the rest, $10(66.6 \%)$ cases were following Lower Segment Caesarian Section (2-elective, 8-emergency) (Table 2). Mean gestational age at termination of pregnancy was $35.8 \pm 7.1$ weeks. Twelve cases $(80 \%)$ developed AKI early in the postpartum period i.e. first to second postpartum/post-operative day while 1 patient developed $\mathrm{AKI}$ as late as $20^{\text {th }}$ post-operative day. Of the 15 patients, all had raised serum creatinine levels, $12(80 \%)$ were anemic; 6 of them severe and $11(73.3 \%)$ had thrombocytopenia (Table 3 ).

\begin{tabular}{|c|c|c|c|}
\hline & $\begin{array}{l}\text { Creatinine } \\
(\mathrm{mmol} / \mathrm{l})\end{array}$ & $\mathrm{Hb}(\mathrm{gm} / \mathrm{dl})$ & $\begin{array}{l}\text { Plateletes } \\
\left(/ \mathrm{mm}^{3}\right)\end{array}$ \\
\hline Mean & $707.3 \pm 400$ & $7.96 \pm 2.75$ & $86200 \pm 7357$ \\
\hline Minimum & 220 & 3.5 & 26000 \\
\hline Maximum & 1607 & 14.8 & 277000 \\
\hline
\end{tabular}

The commonest etiology of PRAKI was severe preeclampsia and HELLP syndrome along with pregnancy hemorrhages consisting of $4(26.6 \%)$ cases each (Table 4).

\begin{tabular}{|lcl|}
\hline Table 4. Causes of PRAKI $(\mathrm{n}=15)$. & & \\
\hline Cause & N & Percent \\
Severe preeclampsia, HELLP & 4 & 26.6 \\
Pregnancyhemorrhage(APH,PPH) & 4 & 26.6 \\
PROM with sepsis & 2 & 13.3 \\
Obstructed labour with sepsis & 2 & 13.3 \\
Septic abortion & 1 & 6.6 \\
Sepsis with IUFD & 1 & 6.6 \\
Hemolytic Uraemic Syndrome & 1 & 6.6 \\
\hline
\end{tabular}

Hemodialysis was necessary in $12(80 \%)$ cases while $3(20 \%)$ cases improved with medical management consisting of volume resuscitation, appropriate antimicrobials, avoidance of nephrotoxic drugs and other supportive measures. Average days to go into diuresis were $10.25 \pm 5.1$ days. In one patient, plasmapheresis was attempted on suspicion of Thrombotic Thrombocytopenic Purpura (TTP) but there was no response. The average duration of hospital stay was $25.2 \pm 14.7$ days with range of 14 to 71 days. The number of patients needing Intensive Care Unit (ICU) admission were 7(46.6\%), 4(26.6\%) required mechanical ventilation.

The stage of AKI according to RIFLE criteria was as follows: risk in $1(6.6 \%)$, injury in $3(20 \%)$ and failure in $11(73.3 \%)$. Overall $12(80 \%)$ patients had complete recovery in our study with recovery rates of $100 \%$ each for stages of risk and injury while those in the failure stage at diagnosis had a lower recovery rate of $73 \%$ only. Two patients were dialysis dependent at the time of evaluation and there was one mortality due to intractable pulmonary edema (Table 5). 


\begin{tabular}{|c|c|c|c|c|}
\hline \multicolumn{5}{|c|}{ Outcome according to stage } \\
\hline & RIFLE & & & \\
\hline OUTCOME & RISK & INJURY & FAILURE & Total \\
\hline $\begin{array}{l}\text { Complete } \\
\text { recovery }\end{array}$ & 1 & 3 & 8 & $\begin{array}{l}12 \\
(80 \%)\end{array}$ \\
\hline $\begin{array}{l}\text { Partial } \\
\text { recovery }\end{array}$ & 0 & 0 & 1 & $\begin{array}{l}1 \\
(6.6 \%)\end{array}$ \\
\hline ESRD & 0 & 0 & 1 & $\begin{array}{l}1 \\
(6.6 \%)\end{array}$ \\
\hline Mortality & 0 & 0 & 1 & $\begin{array}{l}1 \\
(6.6 \%)\end{array}$ \\
\hline Total & $\begin{array}{l}1 \\
(6.6 \%)\end{array}$ & $\begin{array}{l}3 \\
(20 \%)\end{array}$ & $\begin{array}{l}11 \\
(73.3 \%)\end{array}$ & 15 \\
\hline
\end{tabular}

\section{DISCUSSION}

PRAKI has become a rare entity in the West. New cases of PRAKI have declined from approximately $1 / 3000$ in the 1960 s to $1 / 15,000-20,000$ in recent times. ${ }^{2}$ In France, the incidence of AKI in pregnancy has decreased from $40 \%$ in 1966 to $4.5 \%$ in $1978 .^{9}$ On the other hand, PRAKI is still common during pregnancy in developing countries, being responsible for a high maternal morbidity and mortality. ${ }^{10,11}$ In the Moroccan study by Arrayhani $\mathrm{M}$ et al with sample size of $37(n=37)$ incidence was 6.6 per 1000 deliveries $(0.66 \%)$ while in our study incidence was approximately 2.1 per 1000 deliveries $(0.22 \%) .{ }^{10}$

In our series, PRAKI was more frequent in the postpartum period (93.3\%). This is probably a reflection of reduction in cases in early pregnancy due to legalization of abortion and improving antenatal care. Similar results were obtained in India in a study carried out over two years with a sample size of 40 by Najar et al, where PRAKI occurred during the postpartum in $75.6 \%$ of cases $(n=40)$ while in a study done by Ansari et al over one year with a sample of 42 in Pakistan $(n=42)$, the majority of PRAKI occurred in the 3 rd trimester $(86 \%){ }^{12}$ In our study PRAKI was seen more following emergency LSCS probably due to the indications for LSCS like HELLP or preeclampsia and contributed also by inadequate infection control leading to sepsis.

In most studies from developed countries, preeclampsia/eclampsia was reported to be a major cause of AKI during pregnancy. Pregnancy toxemia was the most common cause of PRAKI (66.6\%), followed by pregnancy hemorrhages (25\%) in a Moroccan study. ${ }^{10}$ Septic abortion was the main cause of PRAKI in a series from Kashmir $(n=40)$ accounting for $20(50 \%)$ cases, 8 hemorrhage $(20 \%)$ cases and 6 toxemia (15\%) cases. ${ }^{11}$ In our study, the main cause of AKI associated with pregnancy was preeclampsia and HELLP syndrome along with pregnancy hemorrhages in $4(26.6 \%)$ cases each, followed by PROM with sepsis and obstructed labor in 2(13.3\%) cases each while septic abortion was seen in only 1 case, probably reflecting the legalization of abortion in our country.

The stage of AKI according to RIFLE criteria in our study: risk in $1(6.6 \%)$, injury in $3(20 \%)$ and failure in $11(73.3 \%)$ cases whereas in the Moroccan study - risk in 40\%; injury in 27\%; and failure in 33\% of cases was seen; probably due to early recognition of kidney injury in their study. Most of our patients were referred cases from outside the Kathmandu valley and that explains the higher stage. ${ }^{10}$ Among the four booked cases in our study, 2(50\%) were in the stage of risk at diagnosis of PRAKI and improved with medical management only, probably because of earlier recognition. In the study by Najar et al $60 \%$ needed dialysis while in our study $80 \%$ needed dialysis likely due to delayed recognition and late stage of presentation of referred cases. ${ }^{11}$

The overall recovery rate of $80 \%$ in our study is comparable with the Moroccan study in which $72.5 \%$ patients recovered completely and in the study by Najar et al in Kashmir, recovery was obtained in $76 \%{ }^{10,11}$ There was one $(6.6 \%)$ maternal mortality in our study compared to $2.7 \%$ in the Moroccan study and $20 \%$ in the study by Najar et al. ${ }^{10,11}$

\section{CONCLUSIONS}

The incidence of PRAKI was higher in our hospital compared to developed countries. Most patients 14 (93.3\%) developed PRAKI in the postpartum period and majority $10(66.6 \%)$ were following LSCS. The commonest etiology of PRAKI was severe preeclampsia and HELLP syndrome along with pregnancy hemorrhages consisting of $26.6 \%$ cases each. Most of the cases were in the failure stage reflecting the late referral of cases to our institute. PRAKI resulted in prolonged hospitalization, ICU 
admission and need for dialysis/transplantation. One patient died. Therefore early recognition of signs and symptoms, close vigilance in high risk cases, early referral and a multidisciplinary team management could potentially prevent progression to higher stages of PRAKI and reduce morbidity and mortality.

\section{DISCLOSURE}

The authors report no conflicts of interest in this work.

No violation of human rights and safety.

Funding: Nil

\section{REFERENCES}

1. Jefferson A, Thurman JM, Schrier RW. Pathophysiology and etiology of acute kidney injury. In: Jurgen F, Johnson RJ, Feehally J, editors. Comprehensive Clinical Nephrology. $4^{\text {th }}$ ed. New York: Elsevier; 2010.

2. Gammill HS, Jeyabalan A. Acute renal failure in pregnancy Crit Care Med. 2005; 33(10):372-84

3. Prakash J, Niwas SS, Parekh A. Acute kidney injury in late pregnancy in developing countries. Ren Fail. 2010;32(3):30913 .

4. Dragun K, Haase M. Acute kidney failure during pregnancy and postpartum. In: Jörres A, Ronco C, Kellum J, editors Management of acute kidney problems. $1^{\text {st }}$ ed. Berlin: Springer;2010:445-58

5. Kuklina EV, Ayala C, Callaghan WM. Hypertensive disorder and severe obstetric morbidity in the United States. Obstet Gynecol. 2009;113(6):1299-316.

6. Martin JN Jr, Blake PG, Perry KG Jr, McCaul JF, Hess LW, Martin RW. The natural history of HELLP syndrome: patterns of disease progression and regression. Am J Obstet Gynecol. 1991;164(6):1500-9.
7. Mehta RL, Kellum JA, Shah SV, Molitoris BA, Ronco C, Warnock DG. Acute Kidney Injury Network: report of an initiative to improve outcomes in acute kidney injury. Crit Care. 2007;11(2):R31.

8. Ricci Z, Cruz DN, Ronco C. Classification and staging of acute kidney injury: beyond the RIFLE and AKIN criteria. Nat Rev Nephrol. 2011;7: 201-8.

9. Utas C, Yalcindag C, Taskapan H, Guven M, Oymak O, Yucesoy M. Acute renal failure in Central Anatolia. Nephrol Dial Transplant. 2000;15(2):152-55.

10. Arrayhani M, Youbi RE, Sqalli T. Pregnancy-related acute kidney injury: experience of the nephrology unit at the University Hospital of Fez, Morocco. ISRN Nephrology 2013. DOI http://dx.doi.org/10.5402/2013/109034

11. Najar MS, Shah AR, Wani IA, Reshi AR, Banday KA, Bhat $\mathrm{MA}$ et al. Pregnancy related acute kidney injury: a single center experience from the Kashmir Valley. Indian J Nephrol. 2008;18(4):159-61.

12. Ansari MR, Laghari MS, Solangi KB. Acute renal failure in pregnancy: one year observational study at Liaquat University Hospital, Hyderabad. J Pak Med Assoc. 2008;58(2):61-4. 